\title{
Edmodo-Based Science Module Development on Students' Mastery of Science Process Skills: Need Analysis
}

\author{
N. Faizah Ahmad, Zanaton Hj Iksan* \\ Faculty of Education, Universiti Kebangsaan Malaysia, Bangi Selangor, Malaysia \\ Email: izahahmad@gmail.com, *zanaton.iksan@ukm.edu.my
}

How to cite this paper: Ahmad, N. F., \& Iksan, Z. H. (2021). Edmodo-Based Science Module Development on Students' Mastery of Science Process Skills: Need Analysis. Creative Education, 12, 2609-2623. https://doi.org/10.4236/ce.2021.1211195

Received: October 17, 2021

Accepted: November 19, 2021

Published: November 22, 2021

Copyright $\odot 2021$ by author(s) and Scientific Research Publishing Inc. This work is licensed under the Creative Commons Attribution International License (CC BY 4.0).

http://creativecommons.org/licenses/by/4.0/

\begin{abstract}
Intensive use of online learning is required in the age of COVID-19 pandemic as all teaching and learning activities had to be done at home. The use of educational social sites such as Edmodo can meet this need, where it has been proven to increase student interest, motivation, collaboration and student achievement. However, not many Edmodo-based module development studies have been conducted, let alone modules that emphasize students' science process skills (SPS), essential in producing science-literate individuals. This study was conducted to identify the need for module development to facilitate teachers to plan activities that implement SPS among students using Edmodo. Difficult themes in form 2 science were also identified. To achieve these objectives, a survey was conducted, and questionnaires were distributed to 51 form two students and 33 science teachers in secondary schools in Negeri Sembilan. Data analysis was performed using descriptive statistics such as percentage and frequency. Form 2 science themes that are difficult for the students are Force and Motion, followed by Heat and then Electricity and Magnetism. The findings also show that teachers and students think that online modules can help improve students' SPS mastery. The analysis also shows that both teachers and students frequently use information and communication technology, the internet and social media for learning purposes or to communicate online. The findings indicate a need for the development of Edmodo-based Science Modules to implement student SPS. With this study, it is hoped that it will help researchers develop Edmodo-based modules based on the needs of teachers and students, thereby helping teachers implement SPS better online.
\end{abstract}

\section{Keywords}

Science Process Skills, Edmodo, Force and Motion, Science Form Two, Social Learning Network 


\section{Introduction}

One of the goals in science education is to acquire Science Process Skills (SPS), a skill required by a person to solve problems and issues faced in daily life (Yang \& Tsai, 2010). In the construction of scientific knowledge and conceptual change, most science curriculum makers acknowledged science process skills as an important tool (Ongowo, 2017). According to Edy Hafizan et al., (2012), a science curriculum that emphasizes SPS will enable students to improve their mastery of critical thinking skills, creative thinking skills and problem-solving skills, which are the skills needed to fulfill future jobs requirements. Moreover, with the acquisition of this SPS, students can use these skills in self-directed learning (Rose Amnah et al., 2013). According to Harlen (1999), mastery of SPS enables students to have a more profound knowledge of learning concepts and content and equips them to acquire meaningful learning in the future.

Students' SPS are not improved if laboratories are not used efficiently (Hofstein \& Naaman, 2007). This is because SPS is most effectively used when designing and conducting scientific investigations (Fazilah et al., 2016). However, the COVID-19 pandemic that has hit the whole world since 2019 does not allow the application of SPS to be done face-to-face in the laboratory. During this pandemic period, educational institutions, especially schools, need to be closed to reduce the spread of the virus that caused the pandemic (Radha et al., 2020). This situation causes drastic changes in the education system from face-to-face learning to web-based or online learning. This also demands science teachers' competence in applying the necessary science skills to students (Heni \& Ghina, 2021). This is not an easy thing to do given the various challenges in implementing this online learning; in addition to teachers also need time to adjust to this new normal. Furthermore, the lack of online teaching resources and materials teachers can use hinders them to apply science skills effectively (Anderman et al., 2012).

This problem can be overcome if teachers are provided with resources and teaching materials such as online modules that facilitate teachers to implement SPS among students. Module-based learning is in line with the constructivist approach in which students actively build their knowledge through group discussions, interacting and acquiring information (Hamidah, 2019). Module-based learning has been widely conducted in various fields such as physics (Suprianto et al., 2018), chemistry (Lee \& Kamisah, 2014), mathematics (Azizah et al., 2020), and science (Candra et al., 2020); however, the use of existing modules is mostly printed modules. The printed module is more focused on providing information but less attractive where it cannot display sound, video, animation and images that clearly explain the concept to be conveyed (Astalini et al., 2019).

Modules developed online to make it easy for teachers and students to access teaching materials anywhere and anytime. According to Hopson et al., (2001), technology-based learning can help students build high-level thinking skills such as analyzing, synthesizing and analyzing, which are directly related to SPS. On- 
line modules using learning social networking (SLN) mediums such as Edmodo can also attract the alpha generation closer to social media than adults. Educators can use this advantage to apply abstract science skills concepts using SLN. Thus, the objectives of this study are as follows:

1) To identify the difficult themes of Science form 2 Secondary School.

2) To identify the need for module development to implement SPS among students by using Edmodo.

\section{Literature Review}

This need analysis study was conducted to obtain information from students and science teachers about the needs of the modules that will be developed to solve the existing problems faced by them. The strength of a module design and development lies in the module's ability to solve problems in a particular context (Richey \& Klein, 2005). The analysis phase is the initial phase in design and development studies where information is gathered from the context and environment under study (DeWitt et al., 2014). This phase also provides essential information in determining the design and development of teaching materials for the next step (Shanmugam \& Balakrishnan, 2019). In the context of this study, a needs analysis study was conducted at the beginning of the module development study to determine the appropriate type of teaching method to apply science process skills (SPS) among students. Thus, this study was conducted to determine teachers and students' needs in using online learning approaches to teach science in schools.

Science process skills are an essential component of scientific skills in science learning. It is a thinking skill used to obtain information, solve problems and formulate results (Safaah et al., 2017). These skills consist of two parts, namely Basic Science Process Skills (BSPS) and Integrated Science Process Skills (ISPS) (Duda \& Susilo, 2019; Özgelen, 2012). The skills of observing, classifying, measuring and using numbers, making inferences, predicting and communicating are BSPS. In contrast, the skills of using space and time, interpreting data, defining operationally, controlling variables, making hypotheses and experimenting are included in ISPS.

To acquire meaningful learning, SPS is vital because learning takes place continuously throughout life. Each individual constantly searches for, interprets, and evaluates the phenomena and problems they face daily in different situations (Karamustafaoğlu, 2011). In addition, SPS helps students develop as individuals who can access knowledge and know how to acquire it (Hikmah et al., 2018). Several previous studies have found a positive relationship between the level of SPS mastery and student achievement in science (Abungu et al., 2014). Due to that, science teachers need to be aware of the importance of improving students' SPS and positive attitudes towards science, as both are among the determinants to student achievement in science.

Conventional teaching approaches are no longer relevant to help develop and 
strengthen students' abilities. Educators need to know how to use a variety of learning and facilitation ( $\mathrm{L} \& \mathrm{~F}$ ) approaches that are appropriate for the $21^{\text {st }}$-century generation that is more towards technology assimilation. Furthermore, with the issue of the Covid-19 pandemic hitting the whole world starting 2019, educational institutions need to be closed to prevent the spread of the epidemic. This caused the learning approach to be changed following the new normals of online learning and self-directed learning (Radha et al., 2020). Nowadays, access to extensive knowledge allows students to learn independently and use online resources (Clark \& Berge, 2005). The current revolution of communication technology and social networks has opened up new opportunities to develop the education system in line with this new normal. The use of technology in education can help students and teachers deal with learning problems that arise due to the current situation. Students can access their classes from different places and at any time. Information technology has become an essential component in any education system (Tarun, 2019).

Edmodo's Learning Social Network (SLN) is one of the top options to be adapted in this online learning. It is an academic social site that allows teachers to teach online and connect teachers with students and their parents (Cheong, 2010). Edmodo was selected in this study due to several factors. Edmodo, developed by Jeff O'Hara and Nick Borg in 2008, is a free online learning medium for various communities such as teachers, students, parents and schools. It is similar to Facebook, which values privacy and security. It only allows teachers to create and manage accounts for their students, where they will get a group code to register in the group, access and join the group (Hamad, 2016). It was also developed solely for academic purposes. Moreover, it is equipped with several functions that help teachers plan their lessons, such as Library, Messages, Progress, Notifications, and 'To-Do' options (Alqahtani, 2019). Edmodo provides educational advantages in enhancing student-teacher interaction, honing writing skills, increasing student engagement in the learning process (Ajjan \& Hartshorne, 2008), and enhancing community spirit among students (Brady et al., 2010).

Learning using SLN with the support of appropriate learning materials can stimulate students' self-learning (Almoeather, 2020). Teaching materials are made to transfer knowledge from teachers to students to promote students' thoughts, feelings, interests and readiness to learn. Digital modules are among the teaching materials suitable for this learning method where they are effective for use in abstract subjects or skills (Serevina et al., 2018).

Among the digital or online module development studies that have been conducted is a study conducted by Lamb \& Annetta (2013), who had found that the online modules they developed can improve students' understanding and attitude towards chemistry subjects. Electronic module development studies had also been conducted by Johari et al. (2016) in Hydrological engineering, Lee \& Kamisah (2010) in electrochemistry and Mulyana \& Sumarmin (2019) in Biology. There were also electronic module design and development which studied 
SPS mastery (Perdana et al., 2017; Pratono et al., 2018), yet not many SPS module development studies use social media such as Edmodo. Thus, there is a gap of online module design and development studies conducted to study students' SPS mastery of using Edmodo in science subjects for form two students. Furthermore, with the Covid-19 pandemic situation plaguing the entire world right now, the development of online modules is much needed by teachers in implementing SPS among students.

\section{Methodology}

\subsection{Research Design}

A module's design and development strength lie in the module's ability to solve problems in a particular context (Richey \& Klein, 2005). The first phase, the analytical phase in design and development studies gathers information from the context and environment under study (Saedah et al., 2013). This phase also provides essential information in determining the design and development of teaching materials for the next phase (Shanmugam \& Balakrishnan, 2019). In the context of this study, this needs analysis study is a survey study to obtain feedback from teachers and students related to online teaching methods to apply SPS among students. This study was also conducted to identify difficult science themes from form 2 to help researchers determine the topics to be used in the module.

\subsection{Respondents}

Two types of samples were used by the researcher; science teachers and form 2 secondary school students. A total of 33 science teachers and 51 students were randomly selected in this study. Anderson (2007) said that the minimum limit of study participants for a survey study is 30 people based on the normal distribution. Only form 2 students and secondary school science teachers were selected for this study because the topic of developing this module is from science form 2 .

\subsection{Data Collections Method}

The instrument used in this study is questionnaires where the questionnaires were answered online in the form of google form. Questionnaires were chosen because this type of data collection requires a short answering time, which makes it easier for respondents to answer. There were two instruments used, namely questionnaires for teachers and questionnaires for students. All the items in the questionnaires were 4-point Likert type scale questions and binary questions. Table 1 shows the dimensions, types and number of items for both questionnaires.

\subsection{Data Analysis Method}

A university lecturer and two experienced science teachers verified all the re- 
search instruments to obtain content validity. The researcher analyzed the data using SPSS software version 24, where descriptive analysis of frequency and percentage was used. Internal reliability was also conducted to determine the validity and reliability of scores from measurement scales (Chua, 2014). According to Noraini, (2013), the higher the alpha value, the higher the internal reliability. This study set a value of Cronbach's Alpha coefficient of 0.7 to be accepted, as suggested by Babbie (2007). It is found that the Cronbach's Alpha value for all items in this instrument is above 0.7. This indicates that the reliability of the items constructed in the questionnaire is acceptable.

\section{Findings and Discussion}

\subsection{What is the Difficult Theme of Science Form 2?}

Findings of the study showed that the form two science themes was found difficult by students, as shown in Table 2. Based on the table, most students found that the three science themes were easy (Ecosystem $=90.2 \%$, Nutrition $=80.4 \%$, Acid and Base $=78.5 \%$ ). Meanwhile, students found the other three themes to be difficult, namely Force and Motion (78.7\%), followed by Heat (69.7\%) and finally, Electricity and magnetism (60.5\%).

Table 1. Questionnaire's dimension, types and number of items.

\begin{tabular}{|c|c|c|c|}
\hline Respondent & Dimension & Types & $\begin{array}{l}\text { Number } \\
\text { of items }\end{array}$ \\
\hline \multirow{3}{*}{ Teacher } & Demography & Binary & 1 \\
\hline & Teaching strategy & 4-point Likert type scale & 8 \\
\hline & The use of ICT in $\mathrm{T} \& \mathrm{~L}$ & 4-point Likert type scale & 7 \\
\hline \multirow{4}{*}{ Student } & Demography & Binary & 2 \\
\hline & Form 2 difficult themes & 4-point Likert type scale & 4 \\
\hline & Commonly used ICT application & Binary & 6 \\
\hline & The use of ICT in learning & Binary & 11 \\
\hline
\end{tabular}

Table 2. Science form 2's difficult themes.

\begin{tabular}{ccccc}
\hline Theme & VD & D & E & VE \\
& N (\%) & N (\%) & N (\%) & N (\%) \\
\hline Ecosystem & $3(5.9 \%)$ & $2(3.9 \%)$ & $7(13.7 \%)$ & $39(76.5 \%)$ \\
Nutrition & $2(3.9 \%)$ & $8(15.7 \%)$ & $18(35.3 \%)$ & $23(45.1 \%)$ \\
Acid and base & $5(9.8 \%)$ & $6(11.8 \%)$ & $21(41.2 \%)$ & $19(37.3 \%)$ \\
Electricity and magnetism & $8(24.2 \%)$ & $12(36.3 \%)$ & $8(24.2 \%)$ & $5(15.2 \%)$ \\
Force and motion & $21(63.6 \%)$ & $5(15.1 \%)$ & $4(12.1 \%)$ & $3(5.9 \%)$ \\
Heat & $15(45.5 \%)$ & $8(24.2 \%)$ & $8(24.2 \%)$ & $2(3.9 \%)$ \\
\hline
\end{tabular}

$\mathrm{VD}=$ Very difficult, $\mathrm{D}=$ Difficult, $\mathrm{E}=$ Easy, $\mathrm{VE}=$ Very easy. 
From the findings, it is clear that the students found that three of the six topics presented were difficult, namely the topics of Electricity and magnetism, Force and motion and Heat. These findings helped the researcher to select topics to use in developing this module. This coincides with the results of previous studies that found that students failed to understand the concept of Force and Motion (Ahmad Tarmimi \& Shahrul Kadri, 2016). In a study conducted by Irwan Shah (2013), the topic of Heat is difficult to master by students in physics because the title contains abstract science concepts. Students have difficulty understanding abstract concepts of physics (Streveler et al., 2003). The relationship between one concept and another can be confusing and make it difficult for students to understand a new and varied concept.

\subsection{Is There a Need for Online Module Development to Apply Science Process Skills?}

Table 3 shows the purpose of the use of ICT by students. The analysis showed that more than $50 \%$ of students use ICT to find information related to learning (90.2\%), download learning materials (72.5\%) and type school assignments (58.8\%). However, less than half use other purposes of using ICT, namely using email (43.1\%), online chat (39.2\%) and social media (41.2\%).

The above analysis shows that students often use online applications for learning purposes, communicate online such as WhatsApp and WeChat, or socialize in social media like Facebook and Instagram. According to Bennett \& Segerberg (2012), the highest number of social media users worldwide is adolescents. There are various learning-based social media sites like Edmodo that teachers and students can take advantage of. Therefore, social media-based online learning modules such as Edmodo are suitable to be developed as the target users of these modules are adolescents.

Findings in Table 4 show a high percentage of all items in the dimension of ICT use in science subjects. Only $11.8 \%$ of students had ever undergone teaching and facilitating ( $\mathrm{T} \& \mathrm{~F}$ ) using Edmodo. The table also shows that almost all students know how to use the internet to find information related to learning $(94.1 \%)$, and $90.2 \%$ of them think that android applications in teaching can attract their interest in this subject.

Table 3. The purpose of the use of ICT among students.

\begin{tabular}{ccc}
\hline Purpose & $\mathbf{N}$ & $\%$ \\
\hline Find information related to learning & 46 & 90.2 \\
Typing school assignments & 30 & 58.8 \\
Use email to communicate & 22 & 43.1 \\
Chat online (ex: WhatsApp) & 20 & 39.2 \\
Using social media & 21 & 41.2 \\
Download learning materials & 37 & 72.5 \\
\hline
\end{tabular}


Table 4. The use of ICT in science learning.

\begin{tabular}{|c|c|c|}
\hline Item & $\mathbf{N}$ & $\%$ \\
\hline I know how to find information using the internet & 48 & 94.1 \\
\hline My science teacher used to use ICT during T \& L & 40 & 78.4 \\
\hline I am interested in learning science online & 35 & 68.6 \\
\hline I am interested if science learning uses interactive multimedia materials & 39 & 76.5 \\
\hline Learning science online helped me understand complex science concepts & 30 & 58.8 \\
\hline $\begin{array}{l}\text { The use of ICT makes it easier for me to understand abstract science } \\
\text { concepts and skills }\end{array}$ & 40 & 78.4 \\
\hline $\begin{array}{l}\text { The use of media in the form of android application models can help me } \\
\text { understand the concepts and content of science. }\end{array}$ & 45 & 88.2 \\
\hline $\begin{array}{l}\text { The use of android applications in teaching will interest me in learning } \\
\text { science }\end{array}$ & 46 & 90.2 \\
\hline My science teacher once used Edmodo in science learning & 6 & 11.8 \\
\hline $\begin{array}{l}\text { If an online science module is developed, it can help me master the ele- } \\
\text { ments of SPS better. }\end{array}$ & 36 & 70.6 \\
\hline
\end{tabular}

The low percentage of use of Edmodo during the $\mathrm{T} \& \mathrm{~F}$ of science indicates that the use of Edmodo is still not widely used compared to its use in western countries. However, the above analysis clearly shows that students often use ICT during science T \& F activities and think that ICT facilitates students to understand complex science concepts and attract students to learn science. Apart from that, students also feel that online modules can help students master the elements of SPS better.

For the dimension of students' SPS mastery, the concept of SPS that was found most easily by students is communication skills which are $88.2 \%$, followed by skills to identify variables, observation skills, inference skills, hypothesis making skills and prediction skills. Only $21.6 \%$ of the students thought that SPS operationally defining skills were easy, as shown in Table 5.

The above findings show that students have problems mastering integrated SPS (ISPS), such as generating hypotheses, making inferences and making predictions. Although most teachers were found not to have difficulties applying the elements of SPS, as shown in Table 6, but it is not the case to some students. This coincides with the findings of a study conducted on secondary school students showed that the mastery of ISPS, namely identifying variables, defining operationally, identifying hypotheses, interpreting data and graphs and designing experiments, are at a moderate level with elements of operationally defining skills are in the lowest level (Ong \& Johairi, 2010; Ongowo, 2017; Yew \& Sunita, 2015). These findings are also supported by a study conducted by Lue (2020). Utami et al. (2017) found that students are weak in mastering the skills of observing and recording data, experimenting and analyzing data. Students could not apply these skills while conducting practical work in the laboratory 
Table 5. Science process skills level of difficulty.

\begin{tabular}{llc}
\hline \multicolumn{1}{c}{ Item } & N & $\%$ \\
\hline I easily understand the concept of SPS, like making hypotheses & 16 & 31.4 \\
I easily understand the concept of SPS, like making observations. & 22 & 43.1 \\
I easily understand the concept of SPS, like making inferences & 18 & 35.3 \\
I easily understand the concept of SPS as communicating & 45 & 88.2 \\
I easily understand the concept of SPS, like making predictions & 12 & 23.5 \\
I easily understand the concept of SPS, such as identifying variables. & 36 & 70.6 \\
I easily understand the concept of SPS, such as defining it operationally & 11 & 21.6 \\
\hline
\end{tabular}

Table 6. Science teaching strategy.

\begin{tabular}{|c|c|c|c|c|}
\hline Item & $\begin{array}{c}\text { SD } \\
\mathrm{N}(\%)\end{array}$ & $\begin{array}{c}\mathrm{D} \\
\mathrm{N}(\%)\end{array}$ & $\begin{array}{c}A \\
N(\%)\end{array}$ & $\begin{array}{c}\text { SA } \\
\text { N (\%) }\end{array}$ \\
\hline $\begin{array}{l}\text { I use a textbook every time my teaching and } \\
\text { facilitating }(\mathrm{T} \& \mathrm{~F}) \text { session }\end{array}$ & $1(3.0)$ & $3(9.1)$ & $4(12.1)$ & $25(75.8)$ \\
\hline $\begin{array}{l}\text { Students quickly understand the concepts of } \\
\text { SPS if explained with the help of media and } \\
\text { graphics }\end{array}$ & $0(0)$ & $0(0)$ & $3(9.1)$ & $30(90.9)$ \\
\hline $\begin{array}{l}\text { I apply the concept of SPS while doing } \\
\text { experiments or practical work }\end{array}$ & $0(0)$ & $0(0)$ & $6(18.2)$ & $27(81.8)$ \\
\hline $\begin{array}{l}\text { I always strive to find the best approach to } \\
\text { apply SPS to students }\end{array}$ & $0(0)$ & $0(0)$ & $8(24.2)$ & $25(75.8)$ \\
\hline $\begin{array}{l}\text { While teaching, I use the Daily Teaching } \\
\text { Plan (DTP) as a guide }\end{array}$ & $1(3.0)$ & $1(3.0)$ & $7(21.1)$ & $24(72.7)$ \\
\hline $\begin{array}{l}\text { There is no element of SPS application in my } \\
\text { DTP }\end{array}$ & $15(45.5)$ & $10(30.3)$ & $5(15.2)$ & $3(9.1)$ \\
\hline I have trouble applying SPS in my teaching & $10(30.3)$ & $7(21.2)$ & $13(39.4)$ & $3(9.1)$ \\
\hline
\end{tabular}

$\mathrm{SD}=$ Strongly disagree, $\mathrm{D}=$ Disagree, $\mathrm{A}=$ Agree, $\mathrm{SA}=$ Strongly agree .

(Feyzioğlu, 2009; Lue, 2020).

Data analysis for teachers was also conducted. There were two dimensions studied: teachers' methods in applying SPS in science teaching and ICT in teaching (see Table 6 and Table 7). It was found that more than half of the teacher used a textbook every time their $\mathrm{T} \& \mathrm{~F}$ session $(87.9 \%)$ and used the Daily Teaching Plan (DTP) as their T \& F guide (93.8\%). 75.8\% of these teachers included the SPS element in their DTP. Half of the respondents were found to have no problem applying SPS elements in their teaching (51.5\%). However, all respondents agreed that this SPS element is applied when they do experiments or practical work. Teachers also agreed SPS could be applied better if media and graphics were used in $\mathrm{T} \& \mathrm{~F}$.

As for the dimension of the use of ICT elements in T \& F, teachers often use ICT in T \& F (87.8\%) and think that ICT helps students understand science's 
Table 7. Use of ICT in teaching.

\begin{tabular}{|c|c|c|c|c|}
\hline Item & $\begin{array}{c}\mathrm{SD} \\
\mathrm{N}(\%)\end{array}$ & $\begin{array}{c}\mathrm{D} \\
\mathrm{N}(\%)\end{array}$ & $\begin{array}{c}\text { A } \\
\text { N (\%) }\end{array}$ & $\begin{array}{c}\text { SA } \\
\text { N (\%) }\end{array}$ \\
\hline I often use ICT while teaching & $0(0)$ & $4(12.1)$ & $6(18.2)$ & $23(69.7)$ \\
\hline $\begin{array}{l}\text { I often encourage students to use the internet } \\
\text { either to find material or to have a reading. }\end{array}$ & $0(0)$ & $4(12.1)$ & $8(24.1)$ & $21(63.6)$ \\
\hline $\begin{array}{l}\text { I think the use of ICT helps students } \\
\text { understand concepts and processes in science. }\end{array}$ & $0(0)$ & $1(3.0)$ & $7(21.1)$ & $25(75.8)$ \\
\hline $\begin{array}{l}\text { The use of android applications in teaching } \\
\text { will attract students to learn }\end{array}$ & $0(0)$ & $0(0)$ & $8(24.2)$ & $25(81.8)$ \\
\hline $\begin{array}{l}\text { The use of media in the form of android } \\
\text { application modules can help students } \\
\text { understand the concepts and content of science. }\end{array}$ & $0(0)$ & $2(6.1)$ & $13(39.4)$ & $18(54.5)$ \\
\hline I used to use the Edmodo android app & $20(60.6)$ & $6(18.2)$ & $3(9.1)$ & $4(12.1)$ \\
\hline $\begin{array}{l}\text { If an online science module is developed, it } \\
\text { can help me apply the SPS element to students }\end{array}$ & $0(0)$ & $0(0)$ & $6(18.2)$ & $27(81.8)$ \\
\hline
\end{tabular}

$\mathrm{SD}=$ Strongly disagree, $\mathrm{D}=$ Disagree, $\mathrm{A}=$ Agree, $\mathrm{SA}=$ Strongly agree .

concepts and processes $(96.9 \%)$. They also encouraged students to use the internet as an additional learning material (87.7\%). In terms of online learning medium, both teacher respondents (100\%) and students (90.2\%) agreed that android applications could help students understand difficult science concepts such as the concept of SPS. Furthermore, both teachers (100\%) and students (70.6\%) agreed that SPS could be better implemented if online modules using android applications were developed. However, most of them (Teachers = $78.8 \%$, Students $=88.2 \%$ ) have never used the Edmodo online learning platform, which has been widely used in foreign countries.

Edmodo has proven effective as a learning medium that supports collaboration among teachers and students (Nurhazirah \& Zaidatul Shakila, 2017) and increases student motivation (Susanti \& Prasetyo, 2020). However, the findings from this study found that the use of Edmodo is not widely used in the respondent schools, although this learning medium has been commonly used in foreign countries. Therefore, with this opportunity, researchers can encourage more extensive use of Edmodo with the development of this module. Edmodo is also available in the form of an android app. According to Zainudin \& Pambudi (2019), learning materials developed using the Edmodo android platform can improve critical thinking skills among students. Therefore, researchers can take this opportunity to establish this online module using this application as both teachers and students think that android applications can attract students interest in science learning. They also agreed that the development of modules with this android application could help students master SPS better.

The needs analysis study requires the researcher to collect information about the context and situation of the study from teachers and students who are also 
targeting users of the module. In the context of this study, the researcher collects information about teachers' existing practices and teachers' needs so that the information obtained can help the researcher produce modules that are able to solve teachers' existing problems. The needs analysis results found that online modules based on android applications should be developed to help teachers apply SPS better. The study's findings show that most teachers agree with the importance of online modules, especially in Covid-19 pandemic situations that require self-directed learning to occur. This module can provide teachers with resources and materials that make it easier to implement SPS online. Apart from that, this study can also identify form 2 science themes that students find difficult. This makes it easier for the researcher to determine the title to be used in developing this module.

\section{Conclusion}

A need analysis study is essential in obtaining information on the content and specifications required in developing a module. However, this study has some limitations, which cause that the study's findings do not represent a larger population. This study is limited to form two students because the modules to be developed are for Form two science teachers and students. This population was selected as they did not undergo a public examination. Therefore, further studies can be conducted using target users in primary schools. Apart from that, this study was also conducted specifically to apply SPS in core science subjects. Therefore, other studies can also be done using pure science subjects such as Biology, Physics and Chemistry. The researcher will use the findings of this need analysis as a guide to design and develop modules in the next phase of module development. The needs analysis findings indicate that Edmodo-based science modules for applying Science Process Skills should be developed.

\section{Acknowledgements}

This research was partially supported by the grant STEM and MINDA: GG-2021-001.

\section{Conflicts of Interest}

The authors declare no conflicts of interest regarding the publication of this paper.

\section{References}

Abungu, H. E., Okere, M. I. O., \& Wachanga, S. W. (2014). The Effect of Science Process Skills Teaching Approach on Secondary School Students' Achievement in Chemistry in Nyando District, Kenya. Journal of Educational and Social Research, 4, 359-372. https://doi.org/10.5901/jesr.2014.v4n6p359

Ahmad Tarmimi, I., \& Shahrul Kadri, A. (2016). Tahap kefahaman dan salah konsep terhadap konsep Daya dan Gerakan dalam kalangan pelajar tingkatan empat. Jurnal Fizik Malaysia, 37, 1090-1101. 
Ajjan, H., \& Hartshorne, R. (2008). Investigating Faculty Decisions to Adopt Web 2.0 Technologies: Theory and Empirical Tests. Internet and Higher Education, 11, 71-80. https://doi.org/10.1016/j.iheduc.2008.05.002

Almoeather, R. (2020). Effectiveness of Blackboard and Edmodo in Self-Regulated Learning and Educational Satisfaction. Turkish Online Journal of Distance Education, 21, 126-140. https://doi.org/10.17718/tojde.728140

Alqahtani, A. S. (2019). The Use of Edmodo: Its Impact on Learning and Students' Attitudes toward It. Journal of Information Technology Education: Research, 18, 1-12. https://doi.org/10.28945/4389

Anderman, E. M, Sinatra, G. M. \& Gray, D. L. (2012). The Challenges of Teaching and Learning about Science in the Twenty-First Century: Exploring the Abilities and Constraints of Adolescent Learners. Studies in Science Education, 48, 89-117. https://doi.org/10.1080/03057267.2012.655038

Anderson, D. E. (2007). Survey Techniques. In Raptor Research and Management Techniques (pp. 89-100). Wilson Ornithological Society.

Astalini, D., Kurniawan, W., Anwar, K., \& Kurniawan, D. A. (2019). Effectiveness of Using e-Module and e-Assessment. International Journal of Interactive Mobile Technologies, 13, 21-39. https://doi.org/10.3991/ijim.v13i09.11016

Azizah, A. N., Kusmayadi, T. A., \& Fitriana, L. (2020). Need Assessment of Mathematics Learning Module Based on Information Technology for Junior High School. International Journal of Multicultural and Multireligious Understanding, 7, 57. https://doi.org/10.18415/ijmmu.v7i7.1715

Babbie, E. (2007). The Practice of Social Research (11th ed.). Thomson Wadsworth.

Bennett, W. L., \& Segerberg, A. (2012). Digital Media and the Personalization of Collective Action: Social Technology and the Organization of Protests against the Global Economic Crisis. Social Media and Democracy: Innovations in Participatory Politics, 2011, 13-38.

Brady, K. P., Holcomb, L. B., \& Smith, B. V. (2010). The Use of Alternative Social Networking Sites in Higher Educational Settings: A Case Study of the e-Learning Benefits of Ning in Education. Journal of Interactive Online Learning, 9, 151-170.

Candra, R., Rahayu, E. S., \& Putra, N. M. D. (2020). Development of Science Module SETS Approach to Strengthen Cognitive Learning Outcomes of Elementary School Students. Journal of Primary Education, 9, 248-257.

https://doi.org/10.15294/jpe.v9i3.37713

Cheong, D. (2010). The Effects of Practice Teaching Sessions in Second Life on the Change in Pre-Service Teachers' Teaching Efficacy. Computers and Education, 55, 868-880. https://doi.org/10.1016/j.compedu.2010.03.018

Chua, Y. P. (2014). Kaedah dan statistik penyelidikan: Asas statistik penyelidikan (Edisi Keti). McGraw Hill Education (Malaysia).

Clark, T., \& Berge, Z. (2005). eLearning, Virtual Schools, and the National Education Technology Plan. In 21st Annual Conference on Distance Teaching and Learning, January (pp. 1-5). University of Wisconsin System.

DeWitt, D., Siraj, S., \& Alias, N. (2014). Collaborative mLearning: A Module for Learning Secondary School Science. Educational Technology and Society, 17, 89-101.

Duda, H. J., \& Susilo, H. (2019). Science Process Skill Development: Potential of Practicum through Problems Based Learning and Authentic Assessment. Anatolian Journal of Education, 3, 51-60. https://doi.org/10.29333/aje.2018.315a

Edy Hafizan, M. S., Lilia, H., \& Meerah, T. S. (2012). Perception, Conceptual Knowledge 
and Competency Level of Integrated Science Process Skill towards Planning a Professional Enhancement Programme. Sains Malaysiana, 41, 921-930.

Fazilah, R., Othman, T., \& Azraai, O. (2016). Aplikasi kemahiran proses sains dalam Pembelajaran Berasaskan Masalah untuk matapelajaran Biologi. Jurnal Kurikulum \& Pengajaran Asia Pasifik, 4, 38-46.

Feyzioğlu, B. (2009). An Investigation of the Relationship between Science Process Skills with Efficient Laboratory Use and Science Achievement in Chemistry Education. Journal of Turkish Science Education, 6, 114-132.

Hamad, M. (2016). Edmodo-A Complete Learning Management System.

Hamidah, M. (2019). Development and Effect of Integrated Science Process Skills Module towards Higher-Order Thinking Skills Based on Edutainment. International Journal of Academic Research in Business and Social Sciences, 9, 919-931. https://doi.org/10.6007/IJARBSS/v9-i2/5638

Harlen, W. (1999). Purposes and Procedures for Assessing Science Process Skills. International Journal of Phytoremediation, 21, 129-144.

https://doi.org/10.1080/09695949993044

Heni, N., \& Ghina, W. (2021). Experiential Learning Methods to Improve Young Children's Science Process Skills during Covid-19 Pandemic. In Proceedings of the 5th International Conference on Early Childhood Education (ICECE 2020) (pp. 14-18). Atlastis Press.

Hikmah, N., Yamtinah, S., Ashadi, \& Indriyanti, N. Y. (2018). Chemistry Teachers' Understanding of Science Process Skills in Relation of Science Process Skills Assessment in Chemistry Learning. Journal of Physics: Conference Series, 1022, Article ID: 012038. https://doi.org/10.1088/1742-6596/1022/1/012038

Hofstein, A., \& Mamlok-Naaman, R. (2007). The Laboratory in Science Education: The State of The Art. Chemistry Education Research and Practice, 8, 105-107. http://citeseerx.ist.psu.edu/viewdoc/download?doi=10.1.1.1038.2930\&rep=rep1\&type= pdf

Hopson, M. H., Simms, R. L., \& Knezek, G. A. (2001). Using a Technology-Enriched Environment to Improve Higher-Order Thinking Skills. Journal of Research on Technology in Education, 34, 109-119. https://doi.org/10.1080/15391523.2001.10782338

Irwan Shah, M. G. (2013). Kajian tentang pola interaksi pelajar serta aktiviti pembelajaran berkesan dalam persekitaran pembelajaran atas talian bagi matapelajaran Fizik (Vol. 148). Tesis Sarjana, UTM.

Johari, I., Malik, S. A., Sharif, A., Johan, R., \& Alias, M. (2016). Analisis keperluan pembangunan Koswer Weblog Multimedia Interaktif dalam pembelajaran kejuruteraan hidrologi. In Prosiding Seminar Kebangsaan Majlis Dekan Pendidikan Universiti Awam Malaysia (pp. 126-145). Pusat Pengajian Ilmu Pendidikan, Universiti Sains Malaysia.

Karamustafaoğlu, S. (2011). Improving the Science Process Skills Ability of Science Student Teachers Using I Diagrams. Eurasian Journal of Physics and Chemistry Education, 3, 26-38. http://www.eurasianjournals.com/index.php/ejpce https://doi.org/10.51724/ijpce.v3i1.99

Lamb, R. L., \& Annetta, L. (2013). The Use of Online Modules and the Effect on Student Outcomes in a High School Chemistry Class. Journal of Science Education and Technology, 22, 603-613. https://doi.org/10.1007/s10956-012-9417-5

Lee, T. T., \& Kamisah, O. (2010). Pembinaan Modul Multimedia Interaktif dengan Agen Pedagogi (IMMPA) dalam pembelajaran elektrokimia: Analisis keperluan. In Prosiding 
Kolokium Kebangsaan Pasca Siswazah Sains \& Matematik 2010 (pp. 25-34). Universiti Pendidikan Sultan Idris.

Lee, T. T., \& Kamisah, O. (2014). Development of Interactive Multimedia Module with Pedagogical Agent (IMMPA) in the Learning of Electrochemistry: Needs Assessment. Research Journal of Applied Sciences, Engineering and Technology, 7, 3725-3732. https://doi.org/10.19026/rjaset.7.727

Lue, I. L. L. P. (2020). Keberkesanan modul lab-madi terhadap kemahiran penghujahan, kemahiran proses sains dan penguasaan konsep resapan dan osmosis. Tesis Dr. Fal, Fakulti Pendidikan, Universiti Kebangsaan Malaysia.

Mulyana, A., \& Sumarmin, R. (2019). Needs Analysis to Development of Biology Module Based on Problem-Solving at Topics of Respiratory and Excretory System to Student of Senior High School Grade XI. Journal of Physics: Conference Series, 1317, Article ID: 012196. https://doi.org/10.1088/1742-6596/1317/1/012196

Noraini, I. (2013). Penyelidikan dalam pendidikan (Edisi Kedu). McGraw Hill Education (Malaysia).

Nurhazirah, A., \& Zaidatul Shakila, M. A. (2017). Potential of Edmodo-An Educational Social Network Sites (ESNS) in Biology Classroom. International Journal of Academic Research in Business and Social Sciences, 7, 1473-1488. https://doi.org/10.6007/IJARBSS/v7-i11/3585

Ong, E. T., \& Johairi, A. R. (2010). Tahap penguasaan kemahiran proses sains bersepadu (KPSB) dalam kalangan pelajar tingkatan 2 di daerah Temerloh. Jurnal Pendidikan Bitara UPSI, 3, 80-99.

Ongowo, R. O. (2017). Secondary Schools Students' Mastery of Integrated Science Process Skills in Siaya County, Kenya. Creative Education, 8, 1941-1956.

https://doi.org/10.4236/ce.2017.812132

Özgelen, S. (2012). Students' Science Process Skills within a Cognitive Domain Framework. Eurasia Journal of Mathematics, Science and Technology Education, 8, 283-292. https://doi.org/10.12973/eurasia.2012.846a

Perdana, F. A., Sarwanto, S., Sukarmin, S., \& Sujadi, I. (2017). Development of e-Module Combining Science Process Skills and Dynamics Motion Material to Increasing Critical Thinking Skills and Improve Student Learning Motivation Senior High School. International Journal of Science and Applied Science: Conference Series, 1, 45.

https://doi.org/10.20961/ijsascs.v1i1.5112

Pratono, A., Sumarti, S. S., \& Wijayati, N. (2018). Contribution of Assisted Inquiry Model of E-Module to Students Science Process Skill. Journal of Innovative Science Education, 7, 62-68.

Radha, R., Mahalakshmi, K., Kumar, V. S., \& Saravanakumar, A. R. (2020). E-Learning during Lockdown of Covid-19 Pandemic: A Global Perspective. International Journal of Control and Automation, 13, 1088-1099.

Richey, R. C., \& Klein, J. D. (2005). Developmental Research Methods: Creating Knowledge from Instructional Design and Development Practice. Journal of Computing in Higher Education Spring, 16, 23-38. https://doi.org/10.1007/BF02961473

Rose Amnah, A. R., Mohamad Sattar, R., Azlin Norhaini, M., Zarina, O., \& Lyndon, N. (2013). Inculcation of Science Process Skills in a Science Classroom. Asian Social Science, 9, 47-57. https://doi.org/10.5539/ass.v9n8p47

Saedah, S., Norlidah, A., DeWitt, D., \& Zaharah, H. (2013). Design and Developmental Research: Emergent Trends in Educational Research. Pearson Malaysia.

Safaah, E. S., Muslim, M., \& Liliawati, W. (2017). Teaching Science Process Skills by Us- 
ing the 5-Stage Learning Cycle in Junior High School. Journal of Physics: Conference Series, 895, Article ID: 012106. https://doi.org/10.1088/1742-6596/895/1/012106

Serevina, V., Sunaryo, Raihanati, Astra, I. M., \& Sari, I. J. (2018). Development of e-Module Based on Problem Based Learning (PBL) on Heat and Temperature to Improve Students' Science Process Skill. TOJET: The Turkish Online Journal of Educational Technology, 17, 26-36. https://files.eric.ed.gov/fulltext/EJ1184205.pdf

Shanmugam, K., \& Balakrishnan, B. (2019). Motivation in Information Communication and Technology-Based Science Learning in TAMIL Schools. Jurnal Pendidikan IPA Indonesia, 8, 141-152. https://doi.org/10.15294/jpii.v8i1.16564

Streveler, R. A., Olds, B. M., Miller, R. L., \& Nelson, M. A. (2003). Using a Delphi Study to Identity the Most Difficult Concepts for Students to Master in Thermal and Transport Science. In ASEE Annual Conference Proceedings (pp. 4447-4454). Amer Society for Engineering.

Suprianto, Kholida, S. I., Andi, H. J., \& Mahardika, I. K. (2018). The Effectiveness of Basic Physics Experiment Module Based on Guided Inquiry Model in Improving Hard Skills and Soft Skills of Prospective Physics Teachers. Jurnal Pendidikan Fisika Indonesia, 14, 52-59. https://doi.org/10.15294/jpfi.v14i2.11579

Susanti, D., \& Prasetyo, Z. K. (2020). The Effects of Online-Based 3D Page Flip Science Module on Elementary School Students' Learning Motivation in Indonesia. In IC4E-2020: 1st International Conference on Cutting-Edge Technologies in Computing and Communications (pp. 141-144). Department of Electronics and Communication Engineering National Institute of Technology Kurukshetra. https://doi.org/10.1145/3377571.3377578

Tarun, I. M. (2019). The Effectiveness of a Customized Online Collaboration Tool for Teaching and Learning. Journal of Information Technology Education: Research, 18, 275-292. https://doi.org/10.28945/4367

Utami, B., Saputro, S., Ashadi, Masykuri, M., Yamtinah, S., \& Widoretno, S. (2017). Development of the Science Skills of Lower Secondary Students in a Chemistry Laboratory Experiment. Pertanika Journal of Social Sciences and Humanities, 25, 41-50.

Yang, F. Y., \& Tsai, C. C. (2010). Reasoning about Science-Related Uncertain Issues and Epistemological Perspectives among Children. Instructional Science, 38, 325-354. https://doi.org/10.1145/3377571.3377578

Yew, W. T., \& Sunita, T. (2015). Tahap pencapaian kemahiran proses sains bersepadu dalam mata pelajaran sains dalam kalangan pelajar tingkatan lima. Journal of Science and Mathematics Letters, 3, 7-14.

Zainudin, Z., \& Pambudi, B. (2019). Developing Critical Thinking Skills-Based Learning Set of Basic Physics Subject Using Edmodo in Android Platform. Jurnal Pendidikan Fisika Indonesia, 15, 14-23. https://doi.org/10.15294/jpfi.v15i1.14350 